\title{
THE EFFECT OF QUALITY, COMMUNICATION AND \\ OUTPUTS OF MARKETING CHANNEL OF CIANJUR PANDANWANGI RICE ON CONSUMER TRUST IN JAVA WEST MARKETING AREA
}

\author{
Endah Lisarini*)1, Eddy Yusuf**), and Sutina**) \\ *) Department of Agribusiness, Faculty of Applied Science, University of Suryakancana, Cianjur \\ Jl. Pasirgede Raya, Bojongherang, Cianjur 43216 \\ **) Post Graduate of Management Science, University of Pasundan Bandung \\ J1. Dr. Setiabuddi No. 193, Bandung 40153
}

\begin{abstract}
The objectives of this study are to examine: 1) the influence of product quality, marketing communications and marketing distribution outlet or output channel on consumer trust; 2) dominant factors that influence consumer trust in Cianjur Pandanwangi rice. A descriptive verification method was conducted in order to get an idea of the four dimensions of product quality, the four dimensions of marketing communications and the three dimensions of the marketing distribution channel in building consumer trust in Cianjur Pandanwangi rice. Consumer trust is reflected in transparency, incentives and partnerships. Semantic Differential with numerical rating scale was used to measure 300 responses collected by cross sectional survey. Data processing was conducted by SEM AMOS 22. The result of analysis shows that product quality and distribution channel have significant effects on consumer trust, while marketing communication channel does not give significant influences on consumer trust. Successive dimensions of quality that have significant influences on consumer trust include the rice glutinious texture, purity, color grain of rice and aroma while the output of distribution channel influential to consumer trust includes the diversity of sales volume and easiness to get Pandanwangi rice. These conditions indicate that consumer confidence is not only built from good product quality and ease of availability but also from appropriate communication media reaching the right target. Consumers will trust Pandanwangi rice is purely from Cianjur if it is communicated clearly and transparently.
\end{abstract}

Keywords: marketing mix, consumer value, cianjur pandanwangi rice

\begin{abstract}
Abstrak: Tujuan Penelitian ini untuk mengkaji: 1) bagaimana pengaruh kualitas produk, komunikasi pemasaran dan luaran saluran distribusi pemasaran terhadap kepercayaan konsumen; 2) faktor dominan yang mempengaruhi kepercayaan konsumen beras Pandanwangi Cianjur. Metode deskriptif verifikatif dilakukan guna mendapatkan gambaran mengenai empat dimensi kualitas produk, empat dimensi komunikasi pemasaran dan tiga dimensi luaran saluran distribusi pemasaran dalam membangun kepercayaan konsumen beras Pandanwangi Cianjur. Kepercayaan konsumen direfleksikan dalam transparansi, insentif dan kemitraan. Semantic Differential dengan numeric rating scale digunakan untuk mengukur 300 tanggapan yang dihimpun secara cross sectional survey. Pengolahan data dilakukan dengan SEM AMOS 22. Hasil analisis menunjukkan bahwa kualitas produk dan luaran saluran distribusi berpengaruh signifikan terhadap kepercayaan konsumen, sementara saluran komunikasi pemasaran tidak memberikan pengaruh berarti pada kepercayaan konsumen. Berturut-turut dimensi kualitas yang memberikan pengaruh berarti terhadap kepercayaan konsumen adalah kepulenan beras, kemurnian, warna butir beras dan aroma. Sementara luaran saluran distribusi yang berpengaruh berarti terhadap kepercayaan konsumen berturut-turut adalah keragaman volume penjualan dan kemudahan untuk mendapatkan beras Pandanwangi. Kondisi tersebut mengindikasikan bahwa kepercayaan konsumen tidak hanya dibangun dari kualitas produk yang baik dan kemudahan ketersediaan saja namun perlu media komunikasi yang tepat cara dan sasarannya. Konsumen akan mempercayai beras Pandanwangi adalah murni dari Cianjur apabila dikomunikasikan dengan jelas dan transparan.
\end{abstract}

Kata kunci: bauran pemasaran, nilai konsumen, beras pandanwangi cianjur

\footnotetext{
${ }^{1}$ Corresponding author:

Email: endahlisarini@yahoo.com
} 


\section{INTRODUCTION}

A number of consumer trust concepts put forward by experts are not confined to trust in partnership or transaction activity but consumer trust in goods or services, trademarks and even corporate image (Parasuraman et al. 1985; Dwyer et al. 1987; Anderson and Narus, 1990; Moorman et al. 1993; Gundlach and Murphy 1993; Singh and Sirdeshmukh, 2000; Sirdeshmukh et al. 2002 in Singh and Amit, 2015). Trust can be built on the company honesty, truth and disclosure of information to consumers (Glen Urban (2005) in Kotler et al. 2012), fulfillment of consumer expectations on products or services consumed (Alkin and Singh, 2005; Sarwar et al. 2012) and ease of consumer to get the needed product (Purwono et al. 2013; Edhole, 2013; Asriani et al. 2014; Clow \& Baack, 2014).

From the discussion of FGD of the Cianjur Pandanwangi Rice Conservation Society (MP3C, 2015) and the preresearch conducted revealed the phenomenon that rice consumers are 'indifferent' to rice packaging that reads Pandanwangi. Consumers cannot distinguish which packaging matches the information on the packaging label. Based on the Geographical Indication book (MP3C, 2015) Pandanwangi rice is rice originally come from Cianjur. The previous research (Sarwar et al. 2012; Ivanauskiene et al. 2014; Nguyen et al. 2013) revealed that consumer trust may have implications for consumer loyalty. Meanwhile, consumer trust can be formed from several things including product quality, relationships and good communication between companies and consumers.

This study was conducted with the aim to examine how and how big the effect of product quality, marketing communications and marketing distribution outlets as part of the marketing mix on consumer trust. The novelty of this study is to verify the relevance of the marketing mix to consumer trust on pure Pandanwangi rice from Cianjur. It is known that rice is an easy leisure goods for consumers to switch to other sellers if they do not believe in the product.

In conveying the marketing mix, the company is expected to create high perceived value for consumers by giving consumers confidence in the image of the company and its products (Urban, 2005). There are four values that can be perceived by the consumer i.e. the values or benefits of the product, service, personnel and image (Bagram et al. 2012). From a number of literature, several matters that can affect consumer trust can be formulated. The quality of a product must be defined through quantifiable product characteristics. Characteristics of products that can meet customer satisfaction is the quality of the product both its performance and its conformance (Newton, 2015). Quality that reflects the superiority of a product is an important component in business development (Ulfah et al. 2016). The quality of rice is a combination of physical and chemical characteristics required for certain use by a particular user. Physical characteristics of milled rice include: degrees of sosoh, white, translucent, grain length/grain, rice head, and foreign body when there is a white part like lime. Meanwhile, the chemical characteristics include: amylose content, gel consistency, and gelatinization temperature (Tarigan \& Kusbiantoro, 2011; Yulianingsih, 2012). The aromatic rice is known for its aroma, taste and its glutinous texture or "kepulenan". The 2-acetyl-1-pyrolyine compound contributes to the aroma of pandan aromatic rice. One of aromatic rice is Pandanwangi rice (Tarigan and Kusbiantoro, 2011).

A number of theories and concepts state that consumer trust is influenced by quality and reliable products and meet customer requirements (Sarwar et al. 2012; Chinomona and Dorah, 2013; Nguyen et al. 2013).

Integrated marketing communications (IMC) refers to integrating all brand promotion methods to promote specific products to target market consumers. IMC can be conducted through marketing communication mix such as advertising, sales promotion, public relations, direct selling, personal selling, social media, etc (Edhole III, 2013; Olujimi, 2014). Two-way marketing communications that inform product and brand choices, can maintain consumer confidence (Public Affairs of Nestle, 2011). One dimension of Consumer Trust is Transparency (Urban, 2005). Transparency explains the degree of information disclosure from the company to the consumer. The low degree indicates the existence of information that is hidden or distorted, otherwise Transparency high degree is completely honest information. What is meant by honest information is the conformity between information submitted to consumers with the facts of products consumed and the absence of irregularities, for example, the information contained on the product packaging while the intended 
transparency of information is the disclosure of information from the company to the consumer without any hidden information. There are eight marketing communication mixes including: a) Advertising; b) Sales promotion; c) Events and Experiences; d) Public relation and publicity; e) Direct marketing; f) Interactive marketing; g) Word of mouth marketing; h) Personal selling (Kotler et al. 2012). Previous theories suggest that commercial communications provide corporate social value or consumer value (Lecturer Association Flaviu Meghisan, 2014).

Marketing distribution channels have the following outputs: a) Lot size i.e. number of units or volumes consumers can consume on a single purchase opportunity. Lot size becomes an important consideration with regard to consumer preferences in buying products in certain sizes; b) Waiting and delivery time i.e. average time required by consumers in waiting at the outlet to get the product. In general, consumers love faster service; c) Spatial convenience i.e. level of convenience for consumers in getting the product, availability of outlets that enable consumers to reach the product; d) Product variety i.e. extent of diversity of a given product type. Generally, consumers prefer more diversities and thus have the opportunity to choose their substitutes; e) Service backups i.e. various after-sales services provided, such as delivery, installation, repair, credit. Consumers will love outlets that provide after-sales service (Kotler et al. 2012).

There are 8 dimensions of Trust that comes from Urban (2005) i.e. transparency, product/service quality, incentive, partnering with customers, cooperating design, product comparison and advice, supply chain, and pervasive advocacy. Integrated Marketing consists of product components, channels and communication to create value for consumers, one of which is consumer trust. Consumer trust on the quality of a product is an attitude that will be manifested in their consumption behavior (Nur et al. 2018). Linking the dimension of consumer trust with Integrated Marketing component, in this study, only studied three dimensions of consumer trust: transparency (degree of information disclosure from company to consumer), incentive (alignment on the trust of company employees as well as fulfillment of consumer needs) and partnership helping consumers or responding to consumer complaints).

\section{METHODS}

This research examined the influence of Pandanwangi rice product quality on Consumer trust. Based on the theories that have been tested (Noe and Arloe, 2010; Indrasari et al. 2010; Tarigan and Kusbiantoro, 2011; Yulianingsih, 2012) quality dimensions of Pandanwangi rice including rice glutinious texture/"kepulenan", color and purity can be determined. Based on the above argument, the following hypotheses can be formulated. H1: There is an influence of product quality on consumer trust. Corporate social values can be both positive and negative. Positive social values are good corporate image while consumer value can be consumer satisfaction and consumer trust. In relation to trust building, this study examined the channels of communication including word of mouth (WOM), advertising, exhibition and publicity. Based on the above argument, the following hypotheses can be formulated. H2: There is an influence of product marketing communications on consumer trust. The previous theories have found that multi-channel sales can increase the company market share by $23 \%$; on the other hand, multi-channel sales have a strong effect on increasing consumer trust (Teltzrow et al. 2007). This study examined the effects of distribution channels on the marketing of lot size, spatial convenience and service backups to consumer confidence. Based on the above argument, the following hypothesis can be formulated. H3: There is an effect of product marketing distribution channel on consumer trust. Furthermore, from the three independent variables mentioned above, it can be seen that they simultaneously influence consumer trust. The derived hypothesis is $\mathrm{H} 4$ that there are simultaneous effects of product quality, marketing communication and the outlet of marketing distribution channels simultaneously on consumer trust.

This research is a quantitative research by applying descriptive verification method. Quantitative research is a study that stems from events that can be measured quantitatively or expressed by numbers or scales (Sarwono, 2006; Prajitno, 2012). In this study, there are two types of variables: independent or exogenous latent variables (X1, X2, and X3) and as dependent or endogenous variable $(Y)$. The relationship between the two types of variables is causal comparative ex post facto i.e. the causal relationship of the dependent variable by the independent variable. Independent variables are the variables that influence consumer confidence in Pandanwangi rice. The independent variables in 
this study included product quality (X1) adopted from a number of theories and previous research (Kotler, 2012; Newton, 2015; Tarigan, 2011; Rini, 2012; Rice Mill Plantation 2012), marketing communications (X2) based on a number of theories (Olujimi, 2014, Baran et al. 2014) and the outlet marketing distribution channel (X3) is based on Mardianto et al. (2005); Kotler (2012); Asriani et al. (2014); Clow and Back (2014). Variable $\mathrm{X} 1$ was measured through dimensions/indicator variables: rice aroma, glunity, grain color and purity. The X2 variable indicator includes word of mouth, advertisement, exhibition and publicity while the variable $\mathrm{X} 3$ was measured through indicators of sales volume, ease of purchase and after sales service/delivery (service backup). The dependent variable studied was Consumer Confidence (Y) based on previous theories and studies (Cater, 2007; Alkin and Singh, 2005; Sarwar et al. 2012). This variable was measured by the variable indicators of: 1) transparency; truth and honesty of the ranks of rice providers on rice information to rice consumers, 2) incentives (stimuli) intended to meet the needs of consumers, and 3) partnerships or assistance received by consumers in recognizing Pandanwangi rice.

Measurement of variable indicators was conducted by using a numeric rating scale. Measurement was made by applying 62 items to the respondents via questionnaires with answer choices using Likert scale with seven scale intervals of scale 1 (Strongly Disagree), 2 (Disagree), 3 (Less Agree), 4 (Neutral), 5 (Less Agree), 6 (Agree) and 7 (Strongly Agree).

The data needed in this research included the primary data and secondary data. The primary data in the form of responses to questions on the questionnaire included the data characteristics of the respondents consisting of the educational background, marital status, number of family members, income per month, and duration of consuming Pandanwangi rice. The other primary data included supporting information submitted directly by rice traders, and rice farmers who are members of the Pandanwangi Cianjur Rice Conservation Society (MP3C). The secondary data came from the institutions of MP3C, BPS Cianjur, Disperindag Cianjur District, National Family Planning Board (BKKBN), FGD, and expert judgments.

The research unit was the final consumers of Pandanwangi rice who has over the past year consumed Pandanwangi-labeled rice spread in Cianjur, Sukabumi,
Bandung, Bekasi and Jakarta areas whose numbers are unknown, so sampling is needed. Sampling technique used in sampling in this research was Cluster Random Sampling. Cluster Random Sampling is a sampling technique in a population that is first grouped on a certain basis. From each cluster, a random sample was taken (Koether, 2012; Sarwono, 2006). The cluster in this study is a city with certain demographic characteristics. The size of the sample is determined by the formula of Solimun (2007), i.e. 5-10 times the magnitude of the indicator variables. In this study, the number of indicator variables was 40 deriving from 4 manifest variables. The researcher took 6 times from the large number of indicator variables, so the number of samples reached 240 respondents; however, to anticipate the existence of respondents who do not respond to the questionnaire, then the number of respondents was added up to 300 respondents. The number of respondents of each city was determined proportionally to the population and level of welfare of the population. The respondents are residents belonging to the welfare family III and the prosperous family III plus. Prosperous Family III is a family that has been able to meet all basic needs, psychological social needs and development needs, but has not been able to meet the needs of self-actualization, such as donating regularly to the community in the form of material and finance for social interests, and participate actively, such as becoming the board of social institutions or foundations of social, religions, art, sports, education and so forth. Meanwhile, the family of prosperous III plus is a family that has been able to meet all their needs, namely, basic needs, social psychological, development and self-actualization, especially in providing tangible and sustainable contributions to the society (BKKBN, 2013). Data were collected through direct consumer meetings, and the other data were collected through observations and interviews.

After the data collected, the questionnaire was processed, and the data were encoded and recapitulated. Furthermore, the validity and reliability were tested, and disposal of data outliers and data normality was conducted with software SPSS 16. The data that met the eligibility requirements were further processed to be analyzed descriptively and verifiably. In the descriptive analysis, classification of responded responses were conducted whereas in the verified analysis, measurements on magnitude on effects of the independent variables over the dependent variable was carried out simultaneously or partially. There was also 
a model fit and feasibility test using SEM - Amos 22 (Santoso, 2014).

From the relationship and effects of the three independent variables on one dependent variable based on a number of theories, it can be arranged a research framework as in Figure 1. From the conceptual framework formed, it is expected that this study resulted in verification that the marketing mix (product quality, marketing communications, and output of marketing distribution channels) affects consumer trust either partially or simultaneously.

\section{RESULTS}

\section{Characteristics of The Respondents}

Based on the demographic background, the respondent characteristic data included: education level, marital status, number of family member, income level per month, duration of consumption of Pandanwangi rice and necessity of buying the product. From the data collected, the characteristics of 300 respondents as in Table 1 can be explained.
Testing of The Validity and Reliability of The Instrument

Validity test is done by comparing $r$ count (CorrectedItem Correlation) with cut-off of 0.3 otherwise valid if $\mathrm{r}$ arithmetic $\geq$ cut-off is 0.3. (Masrun, 1997 in Solimun, 2007) and instruments are considered reliable to produce reliable and feasible data to be further processed if corrected item to total correlation is $\geq 0.6$ ( $\alpha$ Cronbach) (Hair et al. 1998 in Solimun, 2007). The test results show that all of the 16 questions for measuring product quality and marketing communications were entirely valid. Each question to measure the distribution channel outlet and consumer confidence showed a valid result. The reliability test results show that the reliable instrument and all data (62 items from 300 respondents) collected were reliable and feasible to be processed further.

\section{Testing on Data Normality}

Another data feasibility requirement to be processed with Path Analysis was the normality of data. This requirement is intended that advanced data is not processed biased. Data are stated to meet the normal distribution if tested using Kolmogorov - Smirnov method obtain a p-value $>0.05$. The normality test results show that the data met the normal distribution as shown by the statistical test value that all data items were above 0.05 .

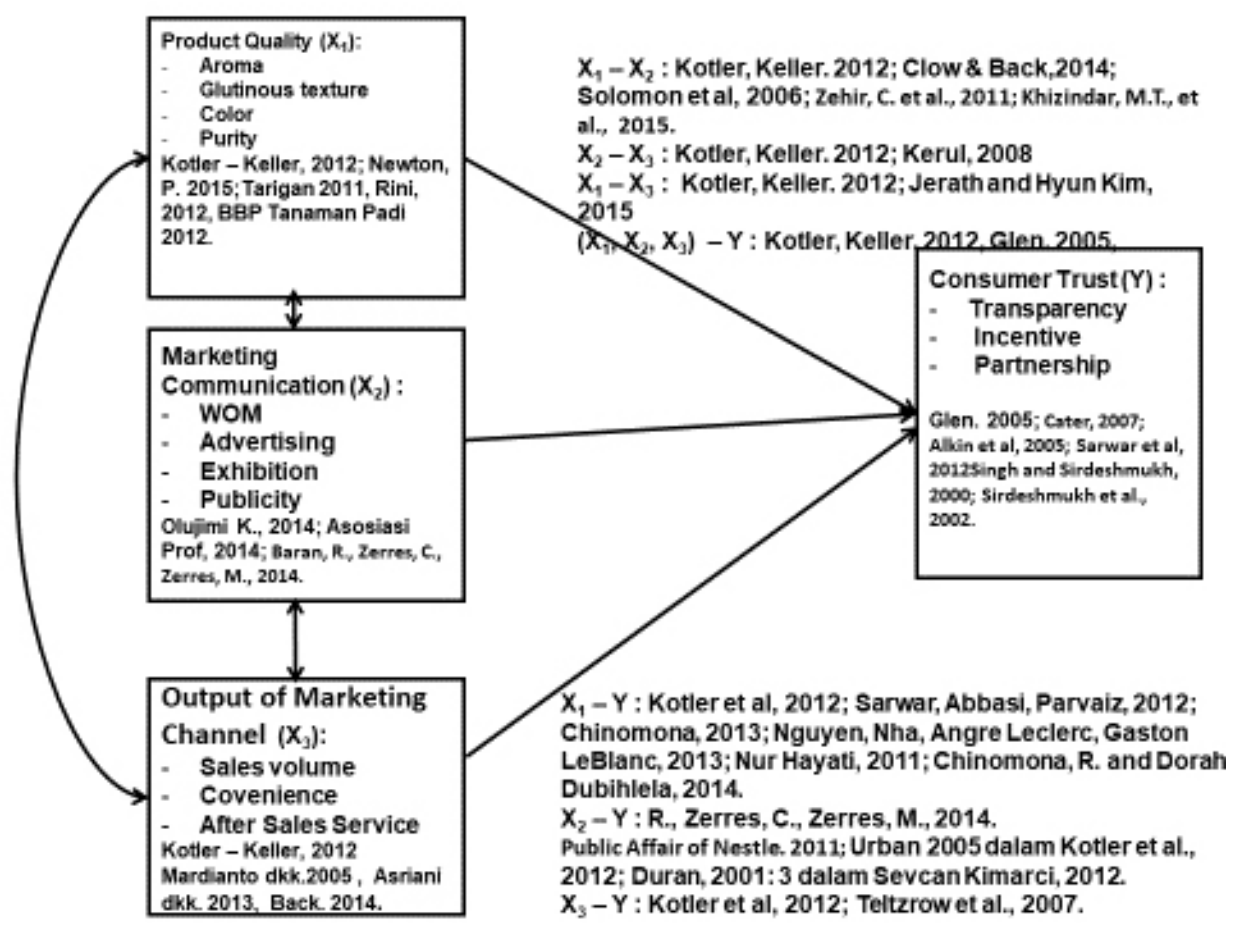

Figure 1. Research framework 
Table 1. Characteristics of the respondents

\begin{tabular}{lc}
\hline Characteristics & Number \\
\hline Place of Origin & \\
Cianjur & 120 \\
Bandung & 65 \\
Bekasi & 18 \\
Bogor & 8 \\
Sukabumi & 3 \\
Jakarta & 86 \\
Education & \\
SD & \\
SMP & 4 \\
SMA & 9 \\
S1 & 62 \\
PASCA & 174 \\
other & 45 \\
Income per Month (million IDR) & 6 \\
$<3$ & \\
$3-6$ & 60 \\
$>6-9$ & 142 \\
$>9$ - 12 & 48 \\
$>12$ & 15 \\
Pandanwangi consumption duration (year) & 35 \\
1 & \\
2 & 89 \\
3 & 45 \\
4 & 67 \\
Marital Status & 99 \\
Married & \\
Unmarried & 270 \\
Consumption for him/herself or for others & 30 \\
Himself/herself & \\
For others & 282 \\
\hline & 18 \\
\hline
\end{tabular}

\section{Descriptive Analysis}

The result of recapitulation of the respondent responses to four variables of research data can be seen in Table 2. From Table 2, it can be explained that the respondents believe that the quality of Pandanwangi rice is excellent in terms of aroma, glutinious texture, grain color and purity. This result is in accordance with the characteristics of Pandanwangi rice which belongs to aromatic special rice based on SNI and MP3C while marketing communications and outsourced marketing distribution channels were responded hesitantly and fairly well. The marketing communication media of word of mouth, advertising, exhibition and publicity were still not able to convince the consumers of pure rice from Pandanwangi Cianjur. This is because information on Pandanwangi has not been fully received correctly by prospective buyers. Only consumers who have more than one year consuming Pandanwangi rice (300 respondents) believe that Pandanwangi rice is a quality rice, easy to obtain when needed.

\section{Verified Analysis}

Verified analysis was carried out by analyzing the variable measurement model, structural model and hypothesis test. The measurement model analysis is conducted to find out whether the indicator variable is a variable that can measure the latent variables (accurate of estimates of parameters). The results of the measurement model analysis and structural model can be seen in Table 3. From the table, it can be concluded that each latent variable was measured well by the indicator variable because all of the loading factor values were above 0.5 . Consumer predominance dominated by incentives, influenced by product quality primarily from the grain color of its rice, is influenced by marketing communications with dominance in advertising and is influenced by the dominance of predominant ease-of-distribution channels. Meanwhile, the structural model constructed from the effects of product quality, marketing communication and the outlet of marketing distribution channel on consumer confidence is a model that has the ability to predict the behavior of explanatory variables from the change of independent variables seen from the determinant coefficient value (R2) from X to Y of 0.749. Overall, the structural model of the relationship between variables can be seen in Figure 2.

Hypothesis testing $(\mathrm{H} 1-\mathrm{H} 4)$ obtained the results as in Table 4 below. $\mathrm{H} 2$ turned out to have an insignificant effect on consumer trust. Based on the fact in the field, it was found that there is a mismatch between the recipients of target information with the recipient of real information. Information on Pandanwangi rice is more intensively socialized to the people in Cianjur in which they are only small part of Pandanwangi rice consumers. On the contrary, the real consumers do not obtain enough information on Pandanwangi rice. However, consumers are proven to still believe in Pandanwangi rice, especially from the color of clear white rice grains and ease of purchase. 
Table 2. Mean value, standard deviation, interval and respondent answer category

\begin{tabular}{lcccc}
\hline \multicolumn{1}{c}{ Variable } & Average & Standard deviation & Interval & Category \\
\hline Product quality & 6.126 & 0.484 & $6.11-7.00$ & Very good \\
Marketing communications & 4.425 & 0.579 & $3.56-4.40$ & Hesitant \\
Output of channel marketing & 5.244 & 0.341 & $4.41-5.25$ & Good enough \\
Consumer trust & 5.338 & 0.280 & $5.26-6.10$ & Trust \\
\hline
\end{tabular}

Table 3. Results of measurement model analysis and structural model

\begin{tabular}{|c|c|c|c|c|c|c|}
\hline \multirow[b]{2}{*}{ Item } & \multicolumn{4}{|c|}{ Standardized regression weight (loading factor) } & \multirow[b]{2}{*}{$\mathrm{R}^{2}$} & \multirow[b]{2}{*}{ Error } \\
\hline & $\begin{array}{l}\text { Product } \\
\text { quality }\end{array}$ & $\begin{array}{c}\text { Marketing } \\
\text { communication }\end{array}$ & $\begin{array}{c}\text { Output of channel } \\
\text { marketing }\end{array}$ & Consumer & & \\
\hline X11 (aroma) & 0.683 & & & & 0.466 & 0.163 \\
\hline X12 (glutinous) & 0.751 & & & & 0.563 & 0.355 \\
\hline X13 (color of rice) & 0.879 & & & & 0.772 & 0.390 \\
\hline X14 (purity of rice) & 0.701 & & & & 0.491 & 0.373 \\
\hline X21 (word of mouth) & & 0.748 & & & 0.560 & 0.904 \\
\hline X22 (advertising)) & & 0.809 & & & 0.655 & 0.759 \\
\hline X23 (exhibition) & & 0.802 & & & 0.644 & 0.863 \\
\hline X24 (publicity) & & 0.758 & & & 0.575 & 0.513 \\
\hline X31 (lot size) & & & 0.761 & & 0.580 & 0.461 \\
\hline X32 (convenience) & & & 0.852 & & 0.727 & 0.622 \\
\hline X33 (after sales service) & & & 0.762 & & 0.581 & 0.249 \\
\hline $\begin{array}{l}\mathrm{X} \text { (product quality, marketing } \\
\text { communications, output of } \\
\text { marketing distribution) }\end{array}$ & & & & Y & 0.749 & 0.251 \\
\hline Y11 (transparency) & & & & 0.851 & 0.724 & 0.255 \\
\hline Y12 (incentive) & & & & 0.868 & 0.754 & 0.174 \\
\hline Y13 (partnership) & & & & 0.774 & 0.599 & 0.383 \\
\hline
\end{tabular}

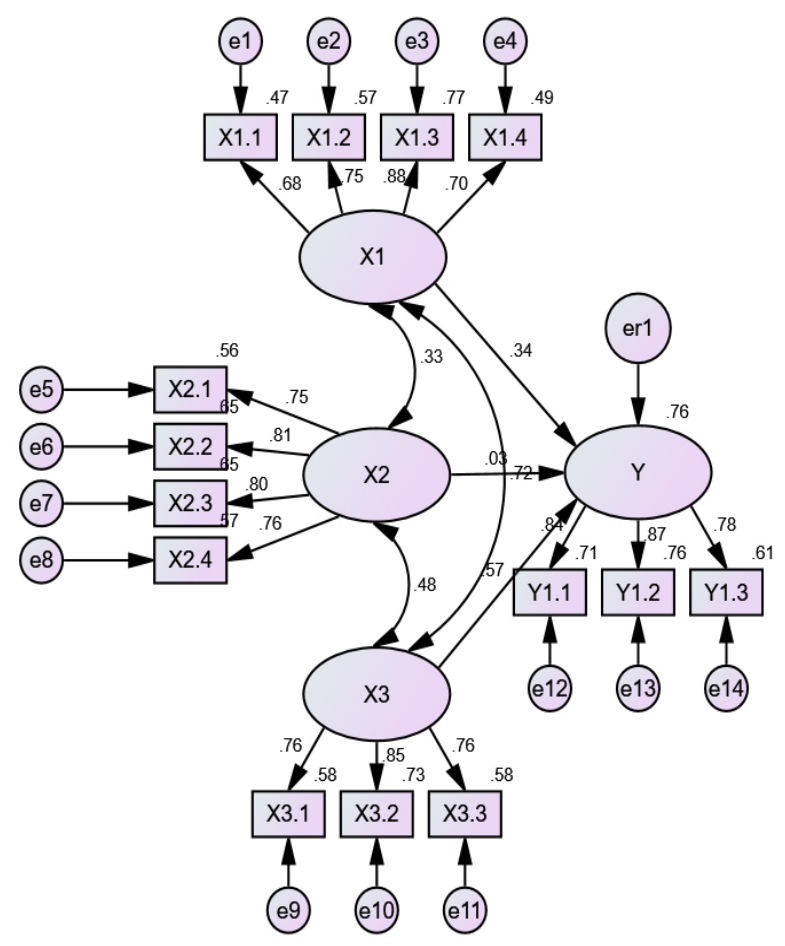

Figure 2. Structure model (product quality relation, marketing communication, output of marketing distribution channels to consumer trust) 
Table 4. Results of hypothesis testing

\begin{tabular}{cccl}
\hline Hypothesis & $\begin{array}{c}\text { Standardized } \\
\text { regression weights }\end{array}$ & P value & \multicolumn{1}{c}{ Conclusion } \\
\hline H1 & 0.354 & 0.000 & There is a significant effect of product quality on consumer trust \\
H2 & 0.065 & 0.186 & There is no significant effect of marketing communication on consumer trust \\
H3 & 0.541 & 0.000 & There is a significant influence of distribution output on consumer trust \\
H4 & 0.762 & 0.000 & $\begin{array}{l}\text { There is a significant effect of product quality, marketing communication and } \\
\text { output of marketing distribution on consumer trust }\end{array}$ \\
\hline
\end{tabular}

\section{Managerial Implication}

If all stakeholders of Pandanwangi rice who are developers and conservationists together maintain good communication with each other and can perform their respective functions and roles, the existence of Pandanwangi rice as Cianjur local wisdom can be maintained. Ultimately, the existence of Pandanwangi rice can contribute to the procurement of staple food in Indonesia.

\section{CONCLUSIONS AND RECOMMENDATIONS}

\section{Conclusions}

From the above mentioned research objectives and from the results of the discussion, it can be concluded that consumer confidence is influenced simultaneously by product quality, marketing communications and distribution outflow by $74.9 \%$ with dominance by product quality. Partially, product quality and output of marketing distribution channel have significant effects while marketing communications have no meaning on the condition of the research. The effect of simultaneously reinforcing the previous theory of marketing mix influential in creating consumer value, especially consumer trust. Meanwhile the result of partial influence indicates a new phenomenon that is not always effective marketing communication. The ineffectiveness of marketing communications is caused by the mistake of targets and communication media that is not appropriate even though the information submitted is correct.

\section{Recommendations}

For stakeholders directly related to the preservation of Pandanwangi (MP3C, Cianjur local government) and Pandanwangi businessmen can build consumer confidence in Pandanwangi special rice as one of the rice Geographical Indications through proper marketing medium communications, targeted consumers, and true and transparent information delivered. Through scientific publications, it is expected that readers and authors in particular can act as a word of mouth to potential customers for their trust on Pandanwangi originally from Cianjur and continue to make purchases. Similar research can be developed by adding the completeness of the marketing mix and encompassing consumers in wider marketing areas.

\section{REFERENCES}

Alkin SMA, Singh R. 2005. Building Consumer Trust. An on-line Perspective. Lulea Unv. Of Technology.

Asosiasi Dosen Flaviu Meghisan. 2014. Ethics and commercial communication. Journal. University of Pitesti Romania.

Asriani PS, Bonodikun, Badrudin R. 2013. Arah Pemasaran Beras Lokal Sebagai Komoditi Pangan Pokok Sumber Karbohidrat Di Provinsi Bengkulu. Di dalam: Kebijakan untuk Petani: Pemberdayaan untuk Pertumbuhan dan Pertumbuhan yang Memberdayakan. Prosiding Konferensi Nasional XVII dan Kongres XVI Tahun 2014; Bogor, 28 - 29 Agu 2014. Bogor: Perhimpunan Ekonomi Pertanian Indonesia. hlm 176-190.

[BKKBN] Badan Kependudukan dan Keluarga Berencana Nasional Direktorat Pelaporan dan Statistik. 2013. Profil Hasil Pendataan Keluarga 2012. Jakarta:BKKBN.

Bagram M, Khan S. 2012. Attaining customer loyalty! the role of consummer attitude and consummer behaviour. Journal of International Review of Management and Business Research 1(1):1-8.

Baran R, Zerres C, Zerres M. 2014. Custome Relationship Management. 1st edition. https:// bookboon.com. [7 march 2014].

Cater B. 2007. The importence of social bonds for communication and trust in marketing 
relationships in proffesional services. Management 13(1): 1-15.

Chinomona R, Dorah D. 2014. Does customer satisfaction lead to customer trust, loyalty and repurchace intention of local store brand? the case of Gauteng Provice South Africa. Mediterranean Journal of Social Sciences 5(9):23.

Clow K, Back D. 2014. Integrated Advertising, Promotion, and Marketing Communications. Pearson: Education South Asia Pte Ltd.

Edhole. 2013. Management Information System. Volume I - II. Education Hole

Indrasari SD, Purwani EY, Widowati S, Djoko SD. 2010. Peningkatan Nilai Tambah Beras Melalui Mutu Fisik, Citarasa dan Gizi. Bogor: Balai Besar Penelitian Tanaman Padi, Balai Besar Penelitian dan Pengembangan Pasca Panen Pertanian, Pusat Penelitian dan Pengembangan Tanaman Pangan.

Koether RT. 2012. Stratified and Cluster Sampling. Hampden - Sydney College.

Kotler P, Kevin LK, Swee HA, Siew ML, Chin TT. 2012. Marketing Management. An Asian Perspective. Pearson: Education South Asia Pte Ltd.

[MP3C] Masyarakat Pelestari Padi Pandanwangi Cianjur. 2015. Buku Persyaratan Permohonan Pendaftaran Indikasi Geografis Beras Pandanwangi Cianjur. Cianjur: MP3C.

Newton P. 2015. Managing Project Quality. Project Skill. www.free-management-ebooks.com.

Nguyen N, Andre L, Gaston L. 2013. The mediating role of cutomer trust on customer loyalty. Journal of Service Science and Management 6:96-109. https://doi.org/10.4236/jssm.2013.61010.

Noe E, Arloe HF. 2010. Quality, Coherence and Cooperation: A Framework for Studying the Mediation of Qualities in Food Network and Collective Marketing Strategies. International Journal of Sociology of Agriculture and Food 18(1): 12-27.

Nur F, Qisthy, Rita N, Megawati S. 2018. Consummer's attitude and willingness to pay for organic rice. Indonesian Journal of Business and Entrepreneurship 4(1):11-21. http://dx.doi. org/10.17358/ijbe.4.1.11.

Olujimi K. 2014. Marketing Communications. 1st edition. bookboon.com.

Prajitno SB. 2012. Metodologi penelitian kuantitatif. http://komunikasi.uinsgd.ac.id.
Public Affair of Nestle. 2011. Nestle Consumer Communication Principles. Nestle Ltd., Vevey Switzerland.

Purwono J, Sugyaningsih S, Priambudi A. 2013. Analisis tata niaga beras di Kecamatan Rogojampi Kabupaten Banyuwangi. Jurnal $\mathrm{NeO}$-Bis 7(2): 136-150. http://dx.doi.org/10.21107/nbs. v7i2.521.

Santoso S. 2014. Amos 22 Untuk Structural Equation Modelling. Konsep Dasar dan Aplikasi. Jakarta: Pt. Elex Media Komputindo, Kompas Gramedia.

Sarwar MZ, Abbasi KS, Parvaiz S. 2012. The effect of customer Trust on customer loyalty and customer retention: a moderating role of cause related marketing. Global Journal of Management and Business Research 12(6):26-36.

Sarwono J. 2006. Metode Penelitian Kuantitatif dan Kualitatif. Yogyakarta:Cetakan I. Graha Ilmu.

Singh V, Amit J. 2015. Consumer trust in retail: development of multiple item scale. Journal of Economic, Business and Management 3(10): 971-976. https://doi.org/10.7763/JOEBM.2015. V3.318.

Solimun. 2007. Multivariate Analysis. Structural Equation Model, Lisrel dan Amos. Malang: Universitas Brawijaya.

Tarigan, Kusbiantoro. 2011. Pengaruh Derajat Sosoh dan Pengemas Terhadap Mutu Beras Aromatik Selama Penyimpanan. Bogor: Balai Besar penelitian Tanaman Padi.

Telzrow M, Bertolt M, Lenz HJ. 2007. Multi-Channel consumer perception. Journal Of Electronic Commerce Reasearch 8(1): 18-31.

Ulfah I, Ujang S, Dodik RN. 2016. Marketing mix factors that influence the desire to purchase fruit beverages in the city of Bogor. Indonesian Journal of Business and Entrepreneurship 2(1): 33-42. https://doi.org/10.17358/ijbe.2.1.33.

Urban G. 2005. Where Are Your Positioned On The Trust Dimension?. Philadelphia: Wharton School Publisher.

Yulianingsih R. 2012. Pengujian Mutu Beras. Bogor: Balai Besar penelitian Tanaman Padi.

Zehir C; Sahin A, Kitapci H, Ozsahin M. 2011. The effect of brand communication and service quality in building brand loyalty through brand trust; the empirical research on global brands. Journal of Procedia Social and Behavioral Sciences 24 (2011): 1218-1231. 